\title{
A case report of pseudohypoaldosteronism type II with a homozygous KLHL3 variant accompanied by hyperthyroidism
}

\author{
Rui Zhang, Simin Zhang, Yingying Luo, Meng Li, Xin Wen, Xiaoling Cai, Xueyao Han ${ }^{*}$ and Linong Ji
}

\begin{abstract}
Background: Pseudohypoaldosteronism type II (PHAll), also called Gordon syndrome, is a rare hereditary disease caused by variants in the WNK1, WNK4, KLHL3 and CUL3 genes. The combination of PHAll with hyperthyroidism and secondary hyperparathyroidism has not been reported previously.

Case presentation: A 54-year-old female with recently diagnosed Graves' disease presented hyperkalemia, hypertension, hypercalciuria, elevated levels of parathyroid hormone (PTH) and normal renal function. PHAll was established based on the finding of a homozygous variant (c.328 A> G, T110A) in the KLHL3 gene. Low-dose thiazide diuretics normalized her potassium, calcium and PTH.

Conclusions: PHAll caused by a KLHL3 variant can affect adults later in life. This diagnosis should be considered in patients with hypertension, consistent hyperkalemia, and normal eGFR and can be corrected by thiazides. The patient also had hyperthyroidism and secondary hyperparathyroidism. The latter was also corrected by thiazide treatment. The hyperthyroidism was assumed to be unrelated to PHAll.
\end{abstract}

Keywords: Pseudohypoaldosteronism type II, Hyperkalemia, Secondary hyperparathyroidism, Hyperthyroidism, Case report

\section{Background}

Pseudohypoaldosteronism type II (PHAII) is a rare hereditary disease characterized by hypertension, hyperkalemia and normal renal function. It is also called Gordon syndrome or familial hyperkalemic hypertension [1]. PHAII could be caused by variants in the With no Lysine Kinases 1 (WNK1), WNK4, Kelch-like 3 (KLHL3) and Cullin 3 (CUL3) genes [2]. These variants commonly lead to increased levels of WNK1/WNK4 protein in distal convoluted tubule (DCT) cells and affect the reabsorption of urinary sodium through the thiazidesensitive $\mathrm{NaCl}$ cotransporter (NCC), resulting in volume expansion and the compensatory reduction of

\footnotetext{
* Correspondence: xueyaohan@sina.com

Department of Endocrinology and Metabolism, Peking University People's

Hospital, No 11, Xizhimen Nan Street, Xicheng District, 100044 Beijing, China
}

aldosterone secretion [3, 4]. Therefore, thiazide diuretics are effective in PHAII.

Graves' disease is one of the most common causes of hyperthyroidism and is caused by an increase in antiTSH-receptor antibody (TRAb) levels [5]. Hyperthyroidism can sometimes lead to hypokalemia and hypokalemic periodic paralysis by driving potassium into cells [6]. In addition, hyperthyroidism is commonly associated with hypercalciuria, but parathyroid hormone (PTH) levels are usually normal or low [7].

Here, we report a case of PHAII with a homozygous KLHL3 gene mutation. The patient also had Graves' disease and elevated PTH levels. To the best of our knowledge, this is the first case report of an adult with PHAII in combination with hyperthyroidism and hyperparathyroidism. We discussed the pathophysiological mechanism associating with the three disorders. 


\section{Case presentation}

A 54-year-old Chinese female came to our hospital because of hyperthyroidism and persistent hyperkalemia as well as an elevated PTH level in October 2018. She first presented with palpitations, fatigue, tremor, and weight loss in August 2017. She visited local doctors and was diagnosed with hyperthyroidism (Graves' disease) with elevated total thyroxine (TT4), total triiodothyronine (TT3), free thyroxine (FT4), free triiodothyronine (FT3), decreased thyrotropin (TSH), and elevated anti-TSHreceptor antibody (TRAb) and an ultrasound presentation of abundant blood flow in the thyroid. Her serum potassium was $5.48 \mathrm{mmol} / \mathrm{L}$ at that time but was not noticed by the doctor. Thiamazole $15 \mathrm{mg}$ daily was given. The patient felt better after the treatment, and the dose of thiamazole was reduced to $10 \mathrm{mg}$ daily. Thyroid function steadily improved during the treatment (Table 1). However, her serum potassium was still elevated, between 5.3 and $5.8 \mathrm{mmol} / \mathrm{L}$. She felt dizzy, with blood pressure measured as 167/94 mmHg in August 2018. She was diagnosed with hypertension, and a combination treatment of metoprolol $25 \mathrm{mg}$ twice a day, nifedipine $30 \mathrm{mg}$ twice a day, and furosemide $40 \mathrm{mg}$ daily was prescribed to her to treat her hyperkalemia at the same time. However, her blood pressure was not well controlled, although she was in good compliance with medication. The serum potassium was still between 5.7 and $5.9 \mathrm{mmol} / \mathrm{L}$.

In one of the routine checks of hyperthyroidism in October 2018, her serum PTH was $123.6 \mathrm{pg} / \mathrm{ml}$ (normal reference range less than $88 \mathrm{pg} / \mathrm{ml}$ ). Then, she visited our clinic, and presented with serum $\mathrm{Ca}^{+}$at $2.39 \mathrm{mmol} /$ $\mathrm{L}$ (normal range 2.2-2.65 mmol/L). PTH was $108.62 \mathrm{pg} /$ $\mathrm{ml}$ (normal range less than $88 \mathrm{pg} / \mathrm{ml}$ ). Twenty-four-hour urinary calcium was $9.52 \mathrm{mmol} /$ day (normal reference range $5.9-6.5 \mathrm{mmol} /$ day), serum $\mathrm{K}^{+}$was $6.18 \mathrm{mmol} / \mathrm{L}$, $\mathrm{Na}^{+}$was $139 \mathrm{mmol} / \mathrm{L}, \mathrm{Cl}^{-}$was $108.6 \mathrm{mmol} / \mathrm{L}$, and total $\mathrm{CO}_{2}$ was $21.2 \mathrm{mmol} / \mathrm{L}$.

She was admitted to the ward of our department at that time. Physical examination showed that her blood pressure was $162 / 80 \mathrm{mmHg}$, her body mass index (BMI) was $29.8 \mathrm{~kg} / \mathrm{m}^{2}$, and her thyroid was enlarged and soft. Further laboratory evaluation still showed elevated potassium and PTH with normal to low serum calcium (Table 2). The urinary calcium was normal in the second test, and arterial blood gas showed metabolic acidosis (Table 2). Biochemical bone markers showed increased bone alkaline phosphatase (ALP) and tartrate resistant acid phosphatase-5b (TRAP-5b), suggesting increased bone turnover. 25-Hydroxyvitamin D was $16.04 \mathrm{nmol} / \mathrm{L}$ (normal range $75-250 \mathrm{nmol} / \mathrm{L}$ ). Her serum creatinine was $57 \mu \mathrm{mol} / \mathrm{L}$, and the estimated glomerular filtration rate (eGFR) was $101.24 \mathrm{ml} / \mathrm{min}^{*} 1.73 \mathrm{~m}^{2}$. Her serum cortisol and ACTH were normal, plasma renin was low or normal, and aldosterone was normal (Table 3). Abdominal ultrasound showed normal images of the pancreas and adrenal gland.

The patient was previously healthy and did not have a family history of hyperkalemia. Her grandmother had been diagnosed with hypertension. Her parents were not consanguineous. Her father died of lung cancer, her mother and brother were healthy, and she did not have any children.

Whole-exome sequencing (WES) of this patient was performed with a BGISEQ-500 platform (Beijing Genomics Institute, Shenzhen, China). A homozygous missense variant in the KLHL3 gene, c.328 A>G (T110A) (NM_01745.3), was identified. The variant was then verified by Sanger sequencing (Fig. 1). The primers for Sanger sequencing were as follows. KLHL3-4 F: AGACAGGGCAGGAGACCATC, KLHL3-4R: AAAATG GTGGGTCCTGAGTG. This variant has not been reported before and does not exist in the ExAC database. The variant was predicted to be likely pathogenic according to the criteria of the American College of Medical Genetics (ACMG) and damaging according to other software programs (SIFT, PolyPhen-2, PROVEAN, CADD, and MutationTaster).

Furosemide $40 \mathrm{mg}$ was stopped and changed to hydrochlorothiazide $25 \mathrm{mg}$ daily, and metoprolol and

Table 1 Thyroid function during treatment

\begin{tabular}{|c|c|c|c|c|c|c|c|}
\hline & $\begin{array}{l}2018-3 \text { (at the diagnosis of } \\
\text { hyperthyroidism) }\end{array}$ & $\begin{array}{l}\text { Normal range in } \\
\text { local clinic }\end{array}$ & $\begin{array}{l}\text { 2018-11-09 (before } \\
\text { thiazide) }\end{array}$ & $\begin{array}{l}\text { 2018-11-20 (after } \\
\text { thiazide) }\end{array}$ & $\begin{array}{l}2019- \\
2-11\end{array}$ & $\begin{array}{l}2019- \\
6-11\end{array}$ & $\begin{array}{l}\text { Normal range in } \\
\text { our hospital }\end{array}$ \\
\hline $\begin{array}{l}\bar{\pi} 4(\mu \mathrm{g} / \\
\mathrm{dl})\end{array}$ & 18.64 & $5.1-14.1$ & 7.1 & 7.0 & & & $3.2-12.6$ \\
\hline $\begin{array}{l}\text { Tा3 (ng/ } \\
\mathrm{dl})\end{array}$ & 328.2 & $80-200$ & 110.07 & 126.29 & & & $60-180$ \\
\hline $\begin{array}{l}\text { FT4 } \\
\text { (pmol/L) }\end{array}$ & 5.7 & $0.93-1.7$ & 15.58 & 15.97 & 16.43 & 16.3 & $11.45-23.17$ \\
\hline $\begin{array}{l}\mathrm{FT3} \\
(\mathrm{pmol} / \mathrm{L})\end{array}$ & 13.46 & $2.0-4.4$ & 5.33 & 5.56 & 5.68 & 4.57 & $3.5-6.5$ \\
\hline $\begin{array}{l}\text { TSH } \\
(\mu \mathrm{U} / \mathrm{ml})\end{array}$ & $<0.005$ & $0.27-4.2$ & 0.008 & 0.005 & 0.004 & 0.097 & $0.55-4.78$ \\
\hline
\end{tabular}


Table 2 Change of electrolytes before and after thiazide

\begin{tabular}{|c|c|c|c|}
\hline & Before thiazide & After thiazide & Normal range \\
\hline$\overline{\mathrm{K}^{+}(\mathrm{mmol} / \mathrm{l})}$ & $5.20-5.44$ & $4.81-5.22$ & $3.50-5.30$ \\
\hline $\mathrm{Na}^{+}(\mathrm{mmol} / \mathrm{l})$ & $138.2-138.8$ & $135.0-138.8$ & $137.0-147.0$ \\
\hline $\mathrm{Cl}^{-}(\mathrm{mmol} / \mathrm{l})$ & $107.1-107.4$ & $101.2-106.0$ & $99.0-110.0$ \\
\hline $\mathrm{Mg}^{2+}(\mathrm{mmol} / \mathrm{l})$ & 0.85 & & $0.7-1.05$ \\
\hline $\mathrm{Ca}^{+}(\mathrm{mmol} / \mathrm{l})$ & $2.09-2.38$ & $2.36-2.46$ & $2.20-2.65$ \\
\hline $\mathrm{P}(\mathrm{mmol} / \mathrm{l})$ & $1.33-1.36$ & $1.17-1.20$ & $0.81-1.45$ \\
\hline PTH $(p g / m l)$ & 119.54 & 69.18 & $12.0-88.0$ \\
\hline $\mathrm{pH}$ value & 7.326 & & $7.35-7.45$ \\
\hline $\mathrm{HCO}_{3}^{-}(\mathrm{mmol} / \mathrm{l})$ & 21.0 & & $22-27$ \\
\hline $\mathrm{BE}(\mathrm{mmol} / \mathrm{l})$ & -4.0 & & $-3.0-3.0$ \\
\hline $\mathrm{AG}(\mathrm{mmol} / \mathrm{l})$ & 14.4 & & $8-12$ \\
\hline Urinary $\mathrm{K}^{+}$(mmol/day) & 48.72 & & $25-100$ \\
\hline Urinary $\mathrm{Na}^{+}$(mmol/day) & 154.0 & & $130-260$ \\
\hline Urinary $\mathrm{Ca}^{+}$(mmol/day) & $5.82-6.90$ & $5.90-6.50$ & $2.50-7.50$ \\
\hline Urinary P (mmol/day) & $23.79-25.72$ & $42.62-45.09$ & $12.90-42.00$ \\
\hline
\end{tabular}

Abbreviations: PTH parathyroid hormone, $B E$ base excess, $A G$ anion gap

nifedipine were continued. Two days later, her potassium decreased to a normal level $(4.87 \mathrm{mmol} / \mathrm{L})$. After discharge from the hospital, her serum potassium remained normal (4.81-5.08 $\mathrm{mmol} / \mathrm{L})$ at follow-up. Her blood pressure was well controlled, under 145/80 $\mathrm{mmHg}$. PTH decreased to the normal range, and serum and urinary calcium were normal (Table 1).

\section{Discussion and conclusions}

PHAII is a rare type of monogenic hypertension characterized by hyperkalemia, metabolic acidosis, hypercalciuria and otherwise normal renal function. It is also described as the opposite of Gitelman syndrome, which presents with hypokalemia, metabolic alkalosis, hypocalciuria and hypomagnesemia [8]. Increased reabsorption of urinary sodium through NCCs in DCT cells is the main pathophysiological mechanism of PHAII. Decreased urinary potassium excretion is secondary to increased $\mathrm{Na}^{+}$reabsorption and leads to hyperkalemia and metabolic acidosis. As a result of hyperkalemia and volume expansion, the renin level is low, and aldosterone is normal or low [4].

Variable mutations in genes including WNK1, WNK4, KLHL3 and CUL3 are reported to be causative for PHAII [2]. WNK (especially WNK4) regulates the activities of NCC, the epithelial $\mathrm{Na}^{+}$channel $\mathrm{ENaC}$, and the
$\mathrm{K}^{+}$channel ROMK in the DCT. Among them, NCC has a crucial role in the development of PHAII. In addition, WNK is controlled through ubiquitination by KLHL3/ CUL3. The KLHL3 protein recruits substrates for CUL3-based ubiquitin ligase complexes and downregulates NCC expression [3]. KLHL3 knockout mice exhibit PHAII-like phenotypes [9]. Hypercalciuria in PHAII may occur due to decreased calcium reabsorption in DCT. The expression of epithelial $\mathrm{Ca}^{+}$channels in the DCT, including transient receptor potential channel vanilloid subtype 5 (TRPV5), TRPV6, and calbindin-D28k (CBP$\mathrm{D} 28 \mathrm{k}$ ), is involved in the mechanism. Animal studies found that mutations in WNK4 downregulate TRPV6 and CBP-D28k and lead to decreased calcium reabsorption [10].

In this case, the patient presented with typical features, including hyperkalemia, hypertension, hypercalciuria and low renin levels, and all of these irregularities were restored to normal by low-dose thiazide diuretics. However, some distinctive features that have not been described in the literature were present in this case. First, a persistently elevated PTH level was discovered and corrected by thiazide diuretics. Second, the patient had hyperthyroidism (Graves' disease). These two features made the diagnostic process more challenging.

Table 3 Renin and aldosterone levels in this case

\begin{tabular}{lccccc} 
& $\begin{array}{l}\text { Supine } \\
\text { position }\end{array}$ & $\begin{array}{l}\text { Normal range of supine } \\
\text { position }\end{array}$ & $\begin{array}{l}\text { Posture } \\
\text { position 1 }\end{array}$ & $\begin{array}{l}\text { Posture } \\
\text { position 2 }\end{array}$ & $\begin{array}{l}\text { Posture } \\
\text { position 3 }\end{array}$ \\
\hline Renin $(\mu \mathrm{l} / \mathrm{l} / \mathrm{ml})$ & 2.7 & $2.8-39.9$ & 4.2 & 3.7 & $\begin{array}{l}\text { Normal range of posture } \\
\text { position }\end{array}$ \\
$\begin{array}{l}\text { Aldosterone } \\
(\mathrm{ng} / \mathrm{dl})\end{array}$ & 4.5 & $3.0-23.6$ & 20.5 & 6.0 & $7.5-46.1$ \\
\hline
\end{tabular}




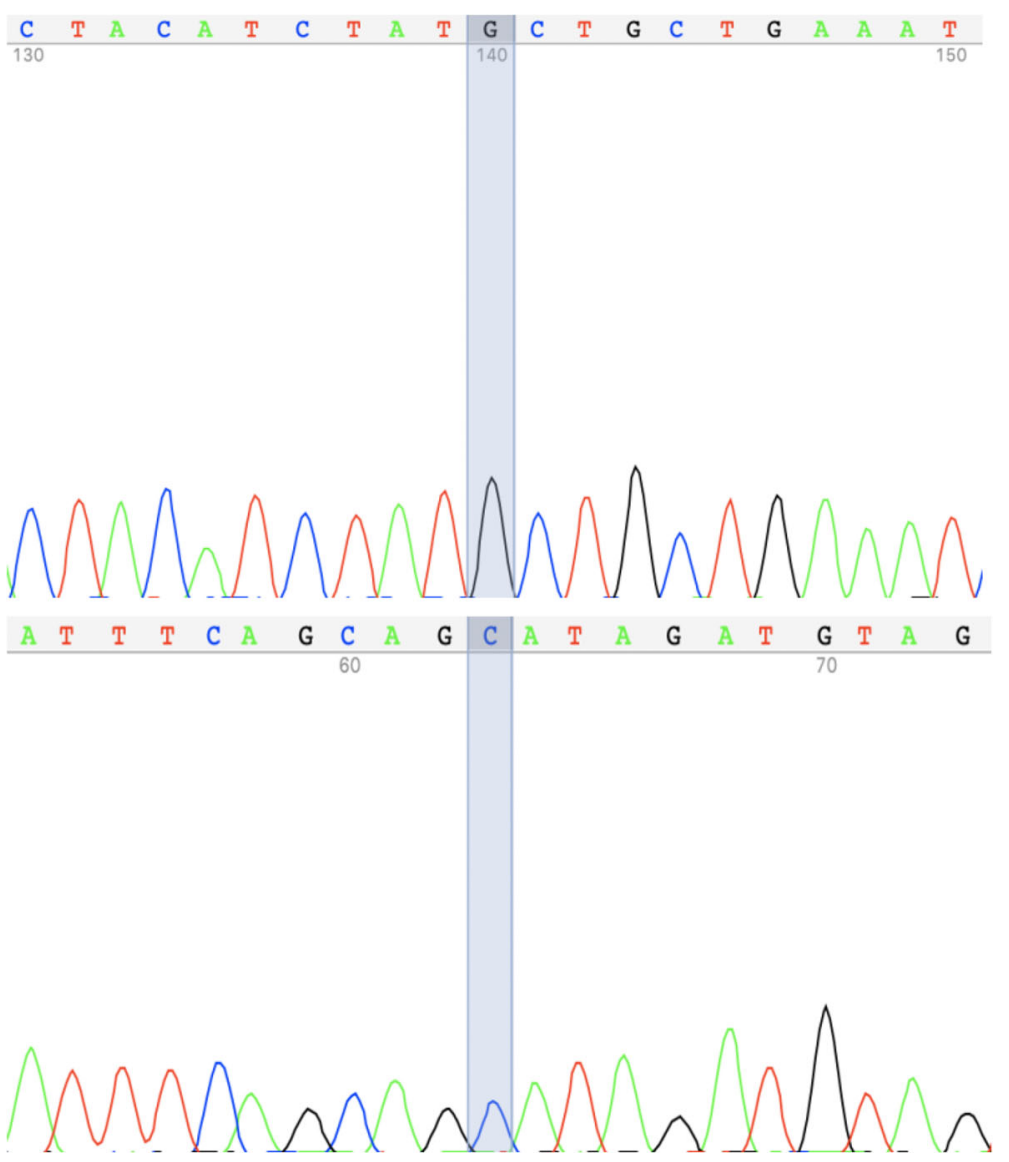

Fig. 1 A homozygous missense variant C.328 A>G (T110A) in the KLHL3 gene by Sanger-Sequencing

Hyperthyroidism can sometimes cause hypokalemia and hypokalemic periodic paralysis by driving potassium into cells, which often occurs among young male patients[6]. Hyperthyroidism can also contribute to hypercalciuria and occasionally hypercalcemia, but PTH levels remain normal or low[7]. Nevertheless, hyperkalemia and increased PTH cannot be explained by hyperthyroidism. Other possible etiologies were considered in the differential diagnosis. Two major causes of hyperkalemia are increased potassium release from cells and reduced urinary potassium excretion. The latter is the most common cause of persistent hyperkalemia. The patient had a normal eGFR and did not use any potassium-sparing diuretics, angiotensin converting enzyme inhibitors or nonsteroidal anti-inflammatory drugs, which can reduce urinary potassium excretion. After the confirmation of PHAII with genetic analysis, we searched previous literature but did not find a combination of hyperthyroidism and PHAII. Thus, we speculate that these two disorders may be unrelated.

Another feature of this case was a persistently elevated PTH level. Although increased urinary calcium can be explained by hyperthyroidism or the use of furosemide [7], the elevated PTH was inconsistent with this

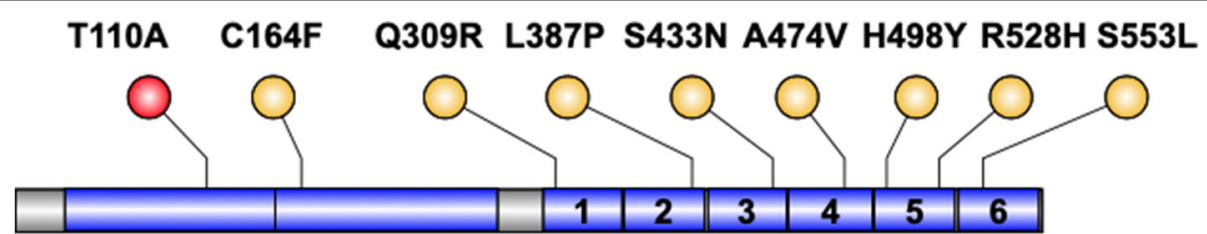

BTB

BACK

Kelch repeat

Fig. 2 The structure of KLHL3 protein and the reported mutation sites 
diagnosis. The low level of 25-hydroxyvitamin D obscured the cause of secondary hyperparathyroidism in this case. Finally, the normalization of calcium and PTH with only thiazides and without vitamin D supplementation excluded the possibility of secondary hyperparathyroidism due to vitamin D deficiency. Thus, we believe that the increase in PTH may be secondary to hypocalcemia as a result of the increased excretion of urinary calcium in PHAII, although a change in PTH in PHAII was not described previously.

PHAII is a hereditary disease, but it may develop at an advanced age. In a cohort study of 52 kindreds including 126 PHAII patients, both dominant and recessive KLHL3 mutations could cause PHAII [2]. The phenotypic severity varies among PHAII patients with different gene mutations. Subjects with CUL3 mutations present at a much younger age and have more severe hyperkalemia and metabolic acidosis. In contrast, patients with KLHL3 mutations may develop hypertension and other symptoms at a later age. In this patient, we found a homozygous c.328 A > G (T110A) variant in KLHL3 that has not been found in previous literature.

Different sites of KLHL3 gene mutations, including H498Y, L387P, C164F, S433N, Q309R, R528H, A474V, and $5553 \mathrm{~L}$, were previously reported in patients with PHAII [11-17]. The KLHL3 protein contains three domains: a BACK (BTB and C-terminal Kelch) domain, an N-terminal BTB (Broad-Complex, Tramtrack and Bric a brac) domain, and a six-bladed $\beta$-propeller structure formed from Kelch-like repeats (Fig. 2) [18]. The T110A

Table 4 Review of the characteristics of PHAll patients with KLHL3 gene mutations

\begin{tabular}{|c|c|c|c|c|c|c|c|c|}
\hline Author & Mutation & Exon & het $/$ hom & Pattern of inheritance & Family history or not & $\begin{array}{l}\text { Age at diagnosis } \\
\text { (years) }\end{array}$ & Sex & $\begin{array}{l}\text { Serum } \\
\text { potassium }\end{array}$ \\
\hline This study & $\mathrm{T} 110 \mathrm{~A}$ & 4 & hom & recessive & sporadic & 56 & M & 5.44 \\
\hline Yang [16] & S433N & 11 & het & dominant & sporadic & 23 & $\mathrm{~F}$ & 6.3 \\
\hline Doan [17] & A474V & 11 & het & dominant & sporadic & 0.16 & $\mathrm{~F}$ & 6.4 \\
\hline \multirow[t]{12}{*}{ Kliuk-Ben Bassat [13] } & S553L & 13 & hom & recessive & pedigree & 1 & M & 7.1 \\
\hline & & & & & & 34 & $\mathrm{~F}$ & 6.2 \\
\hline & Q309R & 8 & het & dominant & pedigree & 63 & M & 5.6 \\
\hline & & & & & & 62 & $\mathrm{~F}$ & 4.8 \\
\hline & & & & & & 57 & M & 5.1 \\
\hline & & & & & & 54 & M & 6.4 \\
\hline & & & & & & 47 & $\mathrm{~F}$ & 5.1 \\
\hline & & & & & & 47 & $\mathrm{~F}$ & 5.1 \\
\hline & & & & & & 44 & M & NA \\
\hline & & & & & & 18 & M & 5.2 \\
\hline & & & & & & 15 & $\mathrm{~F}$ & 5.8 \\
\hline & & & & & & 12 & $\mathrm{~F}$ & 5.3 \\
\hline \multirow[t]{10}{*}{ Mayan [12] } & Q309R & 8 & het & dominant & pedigree & 69 & $F$ & 5.4 \\
\hline & & & & & & 48 & $\mathrm{~F}$ & 5.4 \\
\hline & & & & & & 11 & M & 6.4 \\
\hline & & & & & & 11 & M & 7.2 \\
\hline & & & & & & 10 & $\mathrm{~F}$ & 5.3 \\
\hline & $\mathrm{R} 528 \mathrm{H}$ & 13 & het & dominant & pedigree & 38 & $F$ & 5.6 \\
\hline & & & & & & 15 & $\mathrm{~F}$ & 6 \\
\hline & & & & & & 13 & $\mathrm{~F}$ & 6.2 \\
\hline & & & & & & 8 & F & 5.8 \\
\hline & & & & & & 2 & M & 7 \\
\hline \multirow[t]{3}{*}{ Park [11] } & C164F & 4 & het & dominant & sporadic & 0.8 & $F$ & 6.3 \\
\hline & S433N & 11 & het & dominant & pedigree & 1.7 & $F$ & 6.9 \\
\hline & S433N & 11 & het & dominant & pedigree & 23 & $F$ & 6.4 \\
\hline Mitani [14] & L387P & 9 & het & dominant & sporadic & 3 & M & 6.6 \\
\hline Kelly [15] & $\mathrm{H} 498 \mathrm{Y}$ & 13 & het & dominant & pedigree & 18 & M & 7.3 \\
\hline
\end{tabular}


mutation of the present case is in the BTB domain, which has a role in binding to the CUL3 protein. The mutations, including the present case and those in the previous literature, are summarized in Table 4; Fig. 2. Both heterozygous and homozygous mutations were described. The ages of the affected patients ranged from 1 month to 69 years. All of them had typical clinical features, including hypertension and hyperkalemia.

This patient was diagnosed at the age of 54. The absence of the phenotype in her parents and siblings indicates that this variant may be recessive. However, we cannot confirm this hypothesis without pedigree research. Most previous case reports of PHAII were in children or young adults, but there have been adults who were diagnosed later in life[12, 13]. It is not clear why some mutations of KLHL3 can cause PHAII at an advanced age. It is possible that the phenotype of these mutations is milder; functional studies are needed to confirm this hypothesis. Nevertheless, this case highlights the need to consider hereditary diseases in adults and establish the diagnosis by exome sequencing.

In conclusion, we report a case of a middle-aged Chinese woman with PHAII caused by a novel homozygous variant in KLHL3. This is the first case report of PHAII in combination with hyperthyroidism and secondary hyperparathyroidism. We assumed that the hyperparathyroidism was secondary to PHAII and was not associated with the mutation. This rare case reflected the complexity in the differential diagnosis of electrolyte disorders and indicated the importance of genetic analysis in the diagnosis of a hereditary disease.

\section{Abbreviations \\ PHAll: Pseudohypoaldosteronism type II; WNK1: With no lysine kinases 1; WNK4: With no lysine kinases 4; KLHL3: Kelch-like 3; CUL3: Cullin 3; DCT: Distal convoluted tubule; NCC: Thiazide-sensitive NaCl cotransporter PTH: Parathyroid hormone; TSH: Thyrotropin; TRAb: Anti-TSH-receptor antibody; BMI: Body mass index; ALP: Bone alkaline phosphatase; TRAP- 5b: Tartrate resistant acid phosphatase-5b; TRPV5: Transient receptor potential channel vanilloid subtype 5; TRPV6: Transient receptor potential channel vanilloid subtype 6; CBP-D28k: Albindin-D28k; WES: Whole exome sequencing}

\section{Acknowledgements}

The authors thank all the nurses in the ward of the Department of Endocrinology and Metabolism in Peking University People's Hospital.

\begin{abstract}
Authors' contributions
RZ was the physician in charge of the patient and wrote the manuscript. SZ completed the genetic analysis. YL received the patient at the clinic initially and revised the manuscript. ML helped with the genetic analysis. XW was the resident doctor of the patient and reviewed the literature. $X C$ revised the manuscript. XH designed the work and revised the manuscript. LJ supervised the treatment process and revised the manuscript. All authors read and approved the manuscript.
\end{abstract}

\section{Funding}

This work was supported by the National Key Research and Development Program of China (2016YFC1304901, 2018YFC1314100). The funding agencies had no role in the study design, data collection, decision to publish, or preparation of the manuscript.
Availability of data and materials

Data sharing is not applicable to this article as no datasets were generated or analyzed during the current study.

\section{Declarations}

\section{Ethics approval and consent to participate}

The Ethics Committee of Peking University People's Hospital on Human Research approved the study.

\section{Consent for publication}

Written informed consent was obtained from the patient for publication of this case report and any accompanying images. A copy of the written consent is available for review by the Editor of this journal.

\section{Competing interests}

The authors have nothing to disclose.

Received: 3 July 2020 Accepted: 13 May 2021

Published online: 22 May 2021

\section{References}

1. Gordon RD. Syndrome of hypertension and hyperkalemia with normal glomerular filtration rate. Hypertension. 1986;8(2):93-102. PubMed PMID: 3002982.

2. Boyden LM, Choi M, Choate KA, Nelson-Williams CJ, Farhi A, Toka HR, et al. Mutations in kelch-like 3 and cullin 3 cause hypertension and electrolyte abnormalities. Nature. 2012;482(7383):98-102. doi:https://doi.org/10.1038/na ture10814. PubMed PMID: 22266938; PubMed Central PMCID: PMC3278668.

3. Louis-Dit-Picard H, Barc J, Trujillano D, Miserey-Lenkei S, Bouatia-Naji N, Pylypenko O, et al KLHL3 mutations cause familial hyperkalemic hypertension by impairing ion transport in the distal nephron. Nature genetics (2012) 44(4):456 - 60, S1-3. doi: https://doi.org/10.1038/ng.2218. PubMed PMID: 22406640.

4. Pathare G, Hoenderop JG, Bindels RJ, San-Cristobal P. A molecular update on pseudohypoaldosteronism type II. Am J Physiology Renal Physiology. 2013;305(11):F1513-20. https://doi.org/10.1152/ajprenal.00440.2013 PubMed PMID: 24107425

5. Bartalena L. Diagnosis and management of Graves disease: a global overview. Nature reviews Endocrinology (2013) 9(12):724 - 34. doi: https:// doi.org/10.1038/nrendo.2013.193. PubMed PMID: 24126481.

6. el-Shahawy M, Tucker R, Wahner H, Smith RE. Hyperthyroidism and potassium. Jama. 1971;217(7):969. PubMed PMID: 5109379.

7. Alexander RT, Dimke H. Effect of diuretics on renal tubular transport of calcium and magnesium. Am J Physiol Renal Physiology. 2017;312(6):F9981015. https://doi.org/10.1152/ajprenal.00032.2017 PubMed PMID: 28274923

8. Blanchard A, Bockenhauer D, Bolignano D, Calo LA, Cosyns E, Devuyst O, et al Gitelman syndrome: consensus and guidance from a Kidney Disease: Improving Global Outcomes (KDIGO) Controversies Conference. Kidney international (2017) 91(1):24-33. doi: 10.1016/j.kint.2016.09.046. PubMed PMID: 28003083

9. Sasaki E, Susa K, Mori T, Isobe K, Araki Y, Inoue Y, et al. KLHL3 Knockout Mice Reveal the Physiological Role of KLHL3 and the Pathophysiology of Pseudohypoaldosteronism Type II Caused by Mutant KLHL3. Molecular cellular biology (2017) 37(7). doi:https://doi.org/10.1128/MCB.00508-16. PubMed PMID: 28052936; PubMed Central PMCID: PMC5359427.

10. Yang SS, Hsu YJ, Chiga M, Rai T, Sasaki S, Uchida S, et al. Mechanisms for hypercalciuria in pseudohypoaldosteronism type II-causing WNK4 knock-in mice. Endocrinology. 2010;151(4):1829-36. doi:https://doi.org/10.1210/en.2 009-0951. PubMed PMID: 20181799

11. Park JS, Park E, Hyun HS, Ahn YH, Kang HG, Ha IS, et al. Three cases of Gordon syndrome with dominant KLHL3 mutations. Journal of pediatric endocrinology metabolism: JPEM. 2017;30(3):361-4. doi:https://doi.org/10.1 515/jpem-2016-0309. PubMed PMID: 28222034.

12. Mayan H, Carmon V, Oleinikov K, London S, Halevy R, Holtzman EJ, et al. Hypercalciuria in familial hyperkalemia and hypertension with KLHL3 mutations. Nephron. 2015;130(1):59-65. doi: 10.1159/000381563. PubMed PMID: 25925082

13. Kliuk-Ben Bassat O, Carmon V, Hanukoglu A, Ganon L, Massalha E, Holtzman EJ, et al. Familial Hyperkalemia and Hypertension (FHHt) and $\mathrm{KLHL} 3$. Description of a Family with a New Recessive Mutation (S553L) Compared 
to a Family with a Dominant Mutation, Q309R, with Analysis of Urinary Sodium Chloride Cotransporter. Nephron. 2017;137(1):77-84. doi: 10.1159/ 000475825. PubMed PMID: 28511177.

14. Mitani M, Furuichi M, Narumi S, Hasegawa T, Chiga M, Uchida S, et al. A patient with pseudohypoaldosteronism type II complicated by congenital hypopituitarism carrying a KLHL3 mutation. Clinical pediatric endocrinology: case reports clinical investigations : official journal of the Japanese Society for Pediatric Endocrinology. 2016;25(4):127-34. doi:https://doi.org/10.1297/ cpe.25.127. PubMed PMID: 27780982; PubMed Central PMCID: PMC5069541.

15. Kelly D, Rodzlan MR, Jeunemaitre X, Wall C. A novel mutation in KLHL3 gene causes familial hyperkalemic hypertension. QJM. 2016;109(7):487-8. https://doi.org/10.1093/qjmed/hcw043 PubMed PMID: 27026694.

16. Yang Y, Ou Y, Ren Y, Tian H, Chen T. Hypertension Accompanied by Hyperaldosteronism, Hyperkalemia, and Hyperchloremic Acidosis: A Case Report and Literature Review. Case reports in endocrinology (2020) 2020: 1635413. doi: https://doi.org/10.1155/2020/1635413. PubMed PMID: 32774943; PubMed Central PMCID: PMC7396012.

17. Doan D, Chu C, Yancovich S, El-Dahr S, Baliga R. Novel KLHL3 Variant in an Infant With Gordon Syndrome. Clin Pediatr. 2020;59(11):1011-3. doi: 10. 1177/0009922820920938. PubMed PMID: 32462939.

18. Mabillard H, Sayer JA. The Molecular Genetics of Gordon Syndrome. Genes (2019) 10(12). doi:https://doi.org/10.3390/genes10120986. PubMed PMID: 31795491; PubMed Central PMCID: PMC6947027.

\section{Publisher's Note}

Springer Nature remains neutral with regard to jurisdictional claims in published maps and institutional affiliations.

Ready to submit your research? Choose BMC and benefit from:

- fast, convenient online submission

- thorough peer review by experienced researchers in your field

- rapid publication on acceptance

- support for research data, including large and complex data types

- gold Open Access which fosters wider collaboration and increased citations

- maximum visibility for your research: over $100 \mathrm{M}$ website views per year

At $\mathrm{BMC}$, research is always in progress.

Learn more biomedcentral.com/submissions 